\title{
Mircea Ciubotaru, Cercetări de onomastică. Metodă și etimologie, Editura Demiurg Plus, Iași, 2013, 430 p.
}

\author{
Dinu Moscal* \\ Institutul de Filologie Română „A. Philippide”, Str. T. Codrescu 2, 700481 Iași, România
}

Volumul este o antologie de studii de toponimie și antroponimie, dar şi cîteva de lexicografie, ale unui autor cu vocația cercetării, la care se adaugă, în final, trei recenzii, dintre care primele două reprezintă o acțiune „profilactică” îndreptată împotriva autorilor și a publicării de volume care nu ating nici măcar nivelul submediocrităţii.

Cititorul va observa că o mare parte din articolele adunate aici au la bază cercetarea în amănunt a bazinului superior al Bîrladului (cf. p. 8 și 283), atît printr-o anchetă de teren făcută cu profesionalism, cît și printr-o documentare istorică minuțioasă, multe dintre argumentele de ordin istoric pentru stabilirea etimologiilor venind din cercetarea directă a documentelor din arhive. Acest lucru nu este deloc întîmplător, ci ilustrează modul în care se poate detecta etimologia unui toponim, în anumite cazuri şi a lexemului corespondent, autorul insistînd adesea asupra faptului că toponamastica este o știință în care, pe lîngă cunoștințele de ordin lingvistic, este absolut necesară cunoașterea geografică și istorică a obiectului supus cercetării. Exemplificăm acest fapt şi prin aprecierea adusă unei interpretări a unui mare lingvist, şi anume Iorgu Iordan, cu privire la toponimul Valea Haosului: „Pasajul conține numeroase erori de interpretare, surprinzătoare la un lingvist cu un simț al limbii remarcabil, dar de aşteptat la un toponimist fără experiența anchetei directe și cu infime cercetări istorice documentare” (p. 276). Prezentarea atestărilor sau a discuțiilor existente în cazul unui toponim poate părea uneori prea lungă, îndeosebi în situațiile controversate, însă această alegere este menită ilustrării metodei de lucru adecvate pentru încadrarea istorică și geografică a unui toponim. De altfel, etimologia propriu-zisă a unui toponim nu se rezumă la etimologia lingvistică, ci ar trebui, atît cît este posibil, să arate legătura dintre desemnatul etimonului antroponimic sau semnificaţia etimonului lexical și desemnatul toponimului, iar acest lucru este posibil numai prin documentarea istorică și prin anchetă. Importanța acestor două aspecte face obiectul articolui final (deoarece ordinea lor este cea cronologică), „Ancheta directă și documentarea istorică temelii ale cercetării toponimice" (p. 383-390). Un alt articol cu valoare epistemologică este „Toponimie și zoonimie. Observații metodologice și distincții etimologice" (p. 297-306), în care sînt prezentate în detaliu posibilităţile de interpretare ale seriei toponimice La Ursoi / Ursoiul / Ursoaia. Alte observaţii legate de metodologia cercetării toponimice și antroponimice, care apar în diversele studii de caz, se referă la interpretarea surselor provenite din științele conexe, dintre care amintim: lectura și transcrierea numelor din documentele slavo-române (p. 88-89), probleme de metodologie lexicografică (p. 98, 279, 409-429), preluarea informațiilor istorice, geografice şi arheologice în diverse cazuri (Vlașca, Buda, Promoroacele, Movila lui Burcel, Tîrgul de Floci).

Așa cum s-a menționat deja, articolele nu urmează o ordine tematică, însă, pentru un plus de coerență a prezentării acestora, ele ar putea fi încadratepornind de la tema de bază a articolelor-în trei secțiuni generale, dintre care cea mai mare ar fi rezervată toponimiei, unde pot fi incluse și cele ce includ și probleme de lexic, urmată de articolele de lexicografie și etimologie (observații lexicografice și etimologice se regăsesc și în prima secțiune) și o secțiune de antroponimie strictă (toponima personală implică probleme de antroponimie).

Studiul de toponimie de cele mai mari dimensiuni (p. 17-86) este o prezentare detaliată din perspectivă istorică a oiconimelor din bazinul hidrografic al pîrîului Rebricea (bazinul superior al Bîrladului). Este vorba despre o cercetare exhaustivă a istoricului acestor sate în raport cu proprietarii lor (pînă

\footnotetext{
*Adresă de corespondență: dinumoscal@yahoo.com.
} 
la reforma agrară din 1864), ceea ce are ca rezultat stabilirea clară a etimologiei pentru aproape toate numele acestora şi a schimbării lor, precum și a etimologiei multor toponime minore, la care se adaugă şi prezentarea satelor înființate prin împroprietăriri și a cătunelor. Schimbările la nivelul numelui satelor și a hotarelor lor sînt prezentate în schița și în cele două hărți din anexele de la finalul acestui studiu.

Celelalte studii de toponimie, inclusiv cele ce includ probleme de lexic, au în vedere în primul rînd etimologia. Dintre acestea se remarcă, în ceea ce privește drumul către o etimologie dificil de găsit, articolele despre Buda, Promoroacele, Vlașca și Vlăsia, Tìrgul de Floci, iar în ceea ce privește gradul ridicat de dificultate, cele două articole despre Fălciu.

Toponimul Buda şi etimonul său, apelativul budă, sint tratate în două articole (p. 93-118, 119124), prin care se ajunge le sensul și etimologia apelativului de la originea toponimului, pornindu-se de la o documentare atentă asupra locurilor ce poartă acest nume. După o prezentare a tuturor ipotezelor înaintate anterior în privința apelativului budă (p. 9399), în care sînt detectate erorile de metodologie și interpretare din dicționarele de bază, ceea ce a condus la sensul impropriu de 'baracă', regăsit la geografi, la toponimiști și chiar la istorici, măcar că aceștia din urmă s-au ocupat de editarea textelor în care apar toponimele Buda, autorul reia analiza documentelor referitoare la aceste bude sau în care apare toponimul Buda și ajunge la soluția corectă a etimologiei apelativului, adică 'loc de exploatare a potasei sau a silitrei' și implicit a toponimelor Buda, care nu au o bază antroponimică. Partea a doua a primului articol prezintă istoricul acestor bude, în special de pe teritoritoriul Moldovei, și, în final, toponimele Buda cu acest etimon, după ce, în prealabil, este redată o listă cu toponimele care au fost identificate ca fiind lipsite de vreo legătură cu exploatarea de potasă sau silitră (p. 112-113). De asemenea sînt avute în vedere sinonimele pentru budă (cenuşărie, bută), care au condus și la toponimele corespondente. Al doilea articol dedicat acestei problematici, intitulat „Arheologie și toponimie. Despre numele de locuri Buda și Cenuşa / Cenuşăria" discută problemele de interpretare ale arheologilor cu privire la locurile cu acest nume. Întrun alt articol autorul reia problema apelativului $b u d a ̆$, adică a presupusului derivat budişte și a antroponimelor corespondente Buda, Budişte, Budişteanu, ceea ce ar încadra acest articol în cea de-a treia secțiune propusă mai sus.

Articolul „Promoroacele, o metaforă lexicală necunoscută în funcție toponimică” (p. 253-257) identifică sensul metaforic al etimonului, prin interpretarea unui text care explică modul în care se extrăgea silitra: apa rezultată din spălarea pămîntului bogat în azotaţi de sodiu era fiartă în niște cazane, în care se introduceau apoi nişte bețe, pe care se depunea silitra. Această „depunere de cristale de silitră pe un băt, în procesul de fabricare al salpetrului” (p. 257) este un sens figurat al cuvîntului promoroacă. Chiar dacă textul nu este explicit în acest sens, interpretarea este susținută de urmele exploatărilor de silitră din locurile numite ( $\mathrm{La}$ ) Promoroace.

Cîteva articole au în vedere etimologia toponimelor Humulești, Movila Răbîiei, Movila lui Burcel, Podullung și a două schituri dispărute de pe Valea Bîrladului. În „Humuleștii - un model derivativ popular" (p. 269-273) sînt examinate critic etimologiile propuse anterior, după care, pe baza documentelor care atestă prezența mai multor familii ce se numesc Humă (atestate la scurt timp după întemeierea satului la începutul secolului al XVIII-lea), se identifică o bază de derivare Humul, neatestată, dar care se confirmă prin existența unei serii de alte oiconime rezultate printr-un vechi model derivativ popular, în care derivatele păstrează ca interfix articolul bazei antroponimice. În „Mobila Răbîiei. Cî̀teva precizări” (p. 333-337) se infirmă etimologiile anterioare, unele chiar fanteziste, și se dau argumente edificatoare în favoarea unui toponim românesc, desemnînd „o movilă de pe pămîntul stăpînit de un Răbîia”. Un alt articol de aceeaşi factură este și „De la Vilnești la Movila lui Burcel. Observații onomastice și istorice” (p. 87-92), în care este corectată lectura greșită a numelui lui Ivașco Vilna (nu Venea), astfel făcîndu-se și legătura cu satul Vilnești, de pe Telejna, precum și etimologia toponimului Movila lui Burcel din hotarul moșiei Chircești, ai cărei proprietari sînt urmași ai lui Sima Purcel, la rîndul său, strănepot al lui Ivașco Vilna. Prin urmare este vorba despre Movila lui Purcel, ceea ce nu confirmă etimologia populară din cronica lui Neculce. Anexa de la finalul articolului redă arborele genealogic al neamului Purceleștilor, începînd cu strămoșul lor, Ivașcu Vilna, pînă spre jumătatea secolului al XVII-lea. În „Podullung. Un toponim din harta Moldovei a lui D. Cantemir" (p. 13-16) este argumentată prin documete istorice origina sa antroponimică, atestat la $1746 \mathrm{ca}$ Podul 
Lungului. În articolul „Două schituri dispărute de pe Valea Bîrladului” (p. 319-324) se discută localizarea Schitului Mera și relația dintre schitul Mănăstirii Buhăiescului și Poiana Olarului, aflată lîngă schit, care a condus la o localizare a schitului în funcție de această poiană, fapt care ajută la interpretarea corectă a notației Larwe / Larve din hărțile germane de la sfîrșitul secolului al XVIII-lea și începutul secolului al XIX-lea, ca deformare a numelui Olaru.

În „Lexic şi toponimie din Moldova. Toponimie şi zoonimie” (p. 289-295) sînt date explicațiile etimologice pentru toponimele Podul Roş, Podul Verde, Tîrgul Cucului și pentru entopicul vlaştină, iar în „Reflexele ucr. veža în toponimia românească” (p. 205-212) sînt discutate toponimele Veja, Vejul / Văzul și Soveja.

Patru studii abordează etimologii dificile, cu un trecut bogat în discuţiile lingviștilor și ale istoricilor. În două cazuri, autorul reușește să dea o rezolvare definitivă: pentru Vlaşca și Vlăsia, în unul dintre studii, și, într-un alt studiu, pentru Tìrgul de Floci. Toponimul Fălciu, la care autorul revine și într-un al doilea articol, prezintă dificultăți majore în demersul etimologic, însă tocmai acest lucru are ca rezultat o analiză bazată pe argumente lingvistice complexe.

Avînd în vedere importanţa dată de istorici numelui fostului județ de lîngă Dunăre, Vlaşca, și interpretarea dată de geografi pădurii Vlăsiei, studiul „Revizuiri toponimice: Vlașca și Vlăsia” (p. 141188) nu putea să înceapă altfel decît cu o prezentare a întregului șir de explicații și păreri ale istoricilor, ale lingviștilor şi ale geografilor cu privire la aceste două nume. Pînă astăzi circulă o falsă etimologie, pusă în circulație de istorici și de geografi, bazată pe omonimia cu etnonimul vlah (pl. vlahi / vlaşi), și anume că ar fi vorba despre toponime foarte vechi, ce devin astfel probe ale prezenței continue a românilor în Cîmpia Română. Întregul istoric al acestor toponime, cu o bogată documentare, se întinde pe două treimi din paginile articolului (p. 141-173), astfel încît cititorul interesat are în față toate interpretările și argumentele puse în circulație atunci cind autorul își începe demersul în vederea stabilirii etimologiei corecte, care conduce la un rezultat indubitabil: în ambele cazuri, precum și în toate celelalte de pe teritoriile locuite de români, nu poate fi vorba despre un derivat etnonimic, ci au fie o bază antroponimică (Vlasie), fie apelativul de origine slavă vlaşcă 'loc umed, mlăștinos'.
Din această serie a revizuirilor toponimice face parte și studiul „Revizuiri toponimice: Tîrgul (Orașul) de Floci" (p. 189-203), de asemenea cu o explicație a etimologiei bazată pe o omonimie, fără nici un alt argument, fapt probat de autor printr-o demonstrație pe care am putea-o numi „prin reducere la absurd". Prin verificarea tuturor argumentelor pentru un presupus etimon $f l o c$ (de lînă), care nu pot fi nicidecum susținute prin argumente știinţifice, și pe baza analogiei cu alte toponime formate prin plural direct, se ajunge la concluzia absolut pertinentă că este vorba despre un antroponim Floc(e)a, probabil o poreclă, în funcție toponimică.

Al treilea studiu din acestă serie este „Revizuiri toponimice: Fălciul” (p. 213-230), însă aici problematica este de o cu totul altă natură. Ca și în toate celelalte cazuri, întîi este prezentat istoricul etimologiilor propuse (p. 213-222), o etapă necesară în orice discuție etimologică. Originea antroponimică a toponimului este argumentată prin documentele istorice. Documentarea istorică nu aduce însă forme românești sau contexte care să favorizeze explicațiile de ordin fonetic pentru trecerea de la un antroponim cu atestare în aceeași zonă, Falcin, la forma Fălcii / art. Fălciii. Este discutată ipoteza unui plural direct Falcini, care să ajungă la forma Fălcii prin evoluția sonantei $n$ la palatala $n$ și apoi la $i$ pe terenul limbii române, însă lipsa argumentelor de ordin fonetic îl fac pe autor să recurgă la evoluția la un genitiv suspendat a antroponimului Fălcea, și anume Fălcii (< Tîrgul Fălcii), care să ajungă prin schimbare de accent la Fălcii.

Autorul revine la această etimologie într-un nou articol, „Fălciul - o controversă etimologică” (p. 307-318), care este de fapt un răspuns la observațiile și la etimologia propusă de Dragoș Moldovanu (de la un derivat vechi ucrainean), care nu acceptă soluția genitivului suspendat. Contraargumentele aduse de Mircea Ciubotaru acestor observații nu pot fi neglijate, chiar dacă uneori par să apară și unele accente personale în acest răspuns de înaltă ținută științifică. Lipsa palatalizării în cazul celorlalte toponime din aceeași serie (Bohotin, Miletin, Strahotin, Zeletin) este considerată un argument important care ar infirma posibilitatea evoluției Fălcinĭ > Fălciŭ, însă trebuie remarcat că regimul lor este diferit, toate fiind în primul rînd hidronime, chiar dacă unele au și polarizări oiconimice. Trebuie reținut faptul că soluția genitivului suspendat este amendată de însuși susți- 
nătorul ei, schimbarea de accent obligînd la trecerea ei în categoria ipotezelor.

Cîteva articole abordează probleme de lexic, unde autorul ajunge la etimologii sigure, cu o argumentație bazată întotdeauna pe documentarea istorică. Este vorba despre apelativele $b u d \breve{a}$ (p. 135-140), căamin, cămil și cămană (p. 125-134), șargă (p. 278280), voz, vozarcă, (a) vozi, vozie (p. 325-331) și entopicele pentru 'loc umed, mlăștinos' (alături de reflexele din toponimie) (p. 231-251). Problemele de semantică și de etimologie conduc adesea cititorul într-o lume dispărută, pe care autorul o readuce la viaţă prin documentele istorice şi urmărind circulația cuvintelor în spațiul balcanic. În acest sens se remarcă articolul „Note etimologice și semantice: voz, vozarcă, (a) vozi, vozie" (p. 325-331).

Problemele de onomastică apar adesea și în studiile în care sînt tratate toponime personale, însă apar mai pregnant în două articole în care apar și observații lexicale: „Noi observații asupra apelativului budă și a numelor Buda, Budişte și Budişteanu (p. 135-140) și „Lexic și onomastică în centrul Moldovei” (p. 275287), unde sînt discutate toponime cu originea întrun antroponim omonim sau paronim cu un apelativ, ceea ce ar putea conduce la etimologii incorecte. Se poate face observația că, în cazuri precum cel al entopicului sudol (p. 286), este greu de acceptat argumentul absenței sale în trecut într-o arie în care lipsește astăzi. Aceeași problemă apare și în cazul apelativului șiștar (p. 298). Aceeași observație este valabilă și în cazul ariei de răspîndire a entopicului osoi (p. 302, 304).

„Antroponimie, etnologie și istorie. Contribuții ale lui Petru Caraman” (p. 339-382) poate fi considerat prezentarea unei receptări critice a editării lucrării lui Petru Caraman, Conceptul frumuseții umane reflectat in antroponimie la români și in sudestul Europei. Prolegomene la studiul numelui perso- nal. Lucrarea este abordată mai degrabă prin prisma introducerii editorului (Ion H. Ciubotaru), în care meritele lui Petru Caraman sînt supradimensionate. Pentru o viziune corectă asupra contribuției lui Petru Caraman, Mircea Ciubotaru încadrează opera sa în contextul științific european al domeniului antroponimiei din momentul respectiv și o raportează la studiile existente în spațiul românesc. La final sînt făcute și cîteva observații referitoare la modul în care este editată lucrarea.

În finalul volumului sînt adăugate trei recenzii. Primele două sînt mai degrabă niște avertizări pentru cititori și un act reprobator pentru autori (Costea Marinoiu și Constantin Parascan). Calificativul de „rebut din toate punctele de vedere” (p. 391) pe deplin îndreptățit în primul caz, dar ar putea fi aplicat cu ușurință și în al doilea caz, calificat doar ca o „cercetare ratată” (p. 409). Explicaţiile etimologice nu sînt nici măcar fanteziste, iar la lipsa cunoștințelor de istorie şi geografie „se sparie gîndul”, cum spune cronicarul. Răbdarea cititorului este pusă la încercare şi numai la parcurgerea acestor recenzii.

În cea de-a treia recenzie sînt abordate cîteva probleme terminologice şi etimologice și sînt propuse soluții pentru o serie de termeni (49) din valoroasa lucrare a lingvistului basarabean Anatol Eremia, Dicționarul explicativ și etimologic de termeni geografici, binevenite pentru utilizatorii acestui dicționar.

Cercetări de onomastică. Metodă și etimologie adună articole de onomastică, însă argumentația și investigațiile într-un astfel de domeniu îl conduc pe autorul lor prin multele domenii conexe (istorie, geografie, slavistică, arheologie, genealogie, antropologie), ale căror meandre în plan istoric și metodologic le străbate cu măiestrie, sprijinindu-se întotdeauna pe o excelentă documentare, ajungînd la interpretări noi și foarte adesea definitive. 